\title{
Some Major Plant Toxicities of the Western
}

\section{United States}

\section{LYNN F. JAMES AND A. EARL JOHNSON}

Highlight: Poisonous plants rank high among the causes of economic loss to the livestock industry. Losses come not only through death and disability of livestock but through costs associated with interference with management programs such as additional fencing and altered grazing program.

One of the best means of avoiding poisonous plant problems is by complete familiarity with poisonous plants likely to be encountered by livestock. Important plants causing congenital birth defects; plants containing cyanide, oxalate, nitrates, selenium, and pyrrolizidine alkaloids; as well as a few specific plants as larkspurs and hemlock and those producing photosensitization are reviewed briefly and results of more recent research are considered.

Poisonous plants rank high among the causes of economic loss to the livestock industry (Schmitz et al., 1968; Sperry et al., 1968). They take their toll through death of livestock, abortions, birth defects, photosensitization, chronic illnesses, debilitation, etc. Additionally, land managers and livestockmen have significant costs and problems generated by the presence of poisonous plants on ranges and pastures. These include construction of additional fences, altered grazing programs, decreased forage production and utilization, and in some instances, supplemental feeding programs.

The National Academy of Science, 1968, estimated that $8.7 \%$ of the nutritionally sick animals in western United States were sick as a result of eating poisonous plants and it has been estimated (Sampson, 1952) that the mortality rate, due to poisonous plants, of livestock grazing the western ranges approaches $5 \%$.

Approximately $75 \%$ of the land area of the western United States is rangeland. The forage on this land can be utilized only by ruminants, i.e., cattle, sheep, and wildlife, which convert forage into red meat and fiber for human use. However, this is economically feasible only if the ranges can be developed and maintained in productive condition by proper grazing programs. Many of these ranges cannot be properly and fully utilized because of poisonous plants that grow on them. They may also interfere with the development of grazing programs by land management agencies.

One of the first steps in preventing livestock losses due to poisonous plants is to recognize the plants and understand their effects on animals.

\section{Plants Producing Teratogenic Effects in Animals}

For many years the main problem of plant poisoning of livestock was considered to be that of acute intoxication. In recent years, however, another important dimension has been recognized-that of teratology, wherein the congenital malformations are related to dietary factors.

\footnotetext{
Authors are with the U.S. Department of Agriculture, Agricultural Research Service, Western Region, Poisonous Plant Research Labloratory, Logan, Utah 84321

Manuscript received March 20, 1976
}

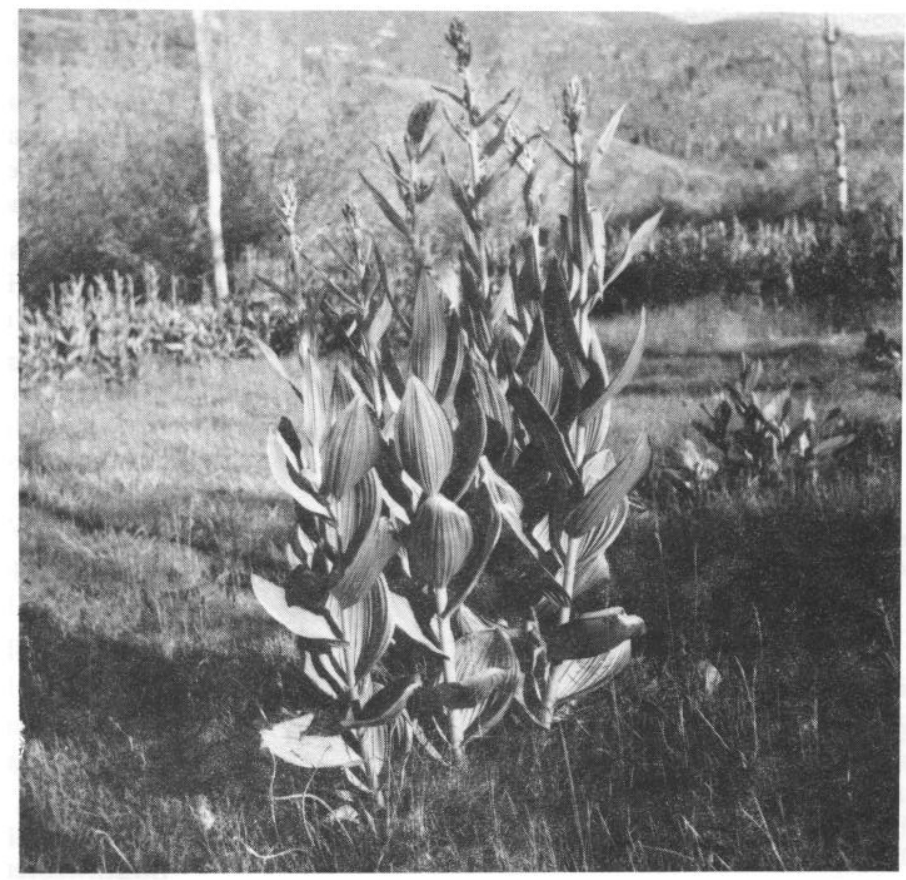

False hellebore (Veratrum californicum) a poisonous plant causing birth defects in lambs.

Several important causes are: deficiencies or excesses of nutrients (Palludon, 1961), chemicals (James and Keeler, 1968), and plants containing natural teratogens (Keeler, 1972).

Veratrum californicum, or western false hellebore, a plant growing in the mountain meadow areas of the West, was shown to be the cause of cyclopian and related cephalic malformations in lambs born to ewes that had ingested the plant on the 14th day of gestation (Binns et al., 1963). This condition occurs in southwestern Idaho, where the incidence varies from less than $1 \%$ to $25 \%$ of the lambs born in a band of sheep. The anomaly is characterized by the following which occur in varying degrees: cyclopia, anophthalmia, kydrocephalus, harelip, cleft palate, and a proboscis protruding above the eye. These deformed lambs may live and continue to grow in utero, and prolonged gestation may occur. Lambs weighing up to $14 \mathrm{~kg}$ have been taken from ewes in prolonged gestation, while the normal birth weight of lambs is about $3.6 \mathrm{~kg}$.

If veratrum is eaten on the 28th or 30th day of gestation, lambs may be born with shortened metatarsal and metacarpal bones (Binns et al., 1972).

Signs of intoxication are rare in ewes producing malformed young.

Approximately 50 to 60 alkaloids occur in the plant, nearly all of which are toxic to animals, but only three are teratogenic. These are the steroidal alkaloids 11-deoxojervine, jervine, and 3-glucosyl-11-deoxojervine (Keeler, 1972).

Research has provided the livestock industry with a practical solution to the problem. Malformations can be avoided by 


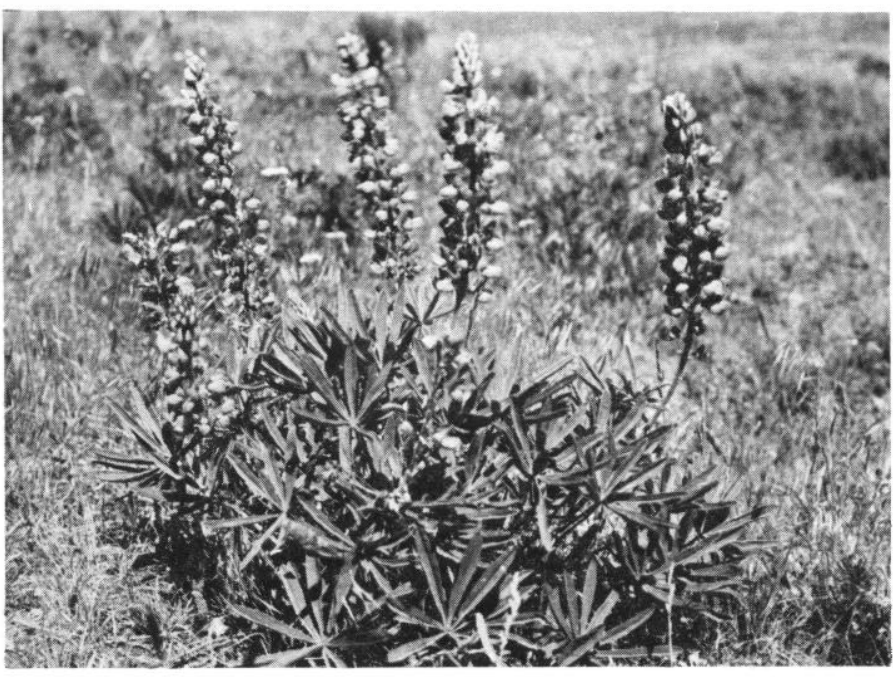

Lupine (Lupinus spp.) a plant which has killed many thousands of sheep and causes defects in calves.

preventing sheep from grazing the $V$. californicum plant during the critical stages of gestation.

Lupinus sericeus and L. caudatus, when ingested by cattle between the 40th and 70th days of gestation cause congenital skeletal malformation in the offspring known as "crooked calf disease" (Shupe et al., 1967). This disease occurs in nearly all the western states and Alaska and herd incidence may vary from 0 to $35 \%$.

The deformity is characterized by malformation of the legs, back, and neck and occasionally by cleft palate (Shupe et al., 1967). Affected calves appear to be normal otherwise. The joints are generally immobile because of a malalignment and malpositioning of the articular surfaces and the limbs are usually rotated laterally. These animals do not recover and the condition should not be confused with contracted tendons, wherein the joints are all in proper alignment without lateral or medial rotation. Joints of calves with contracted tendons can be extended with pressure, whereas the joints of lupine-deformed calves cannot.

Lupine toxicosis is related to the high alkaloid content of the plant. Current research suggests that the teratogenic agent may be the alkaloid anagyrine (Keeler, 1973).

Traditionally, lupine has been considered a poisonous plant affecting primarily sheep and we rarely hear of lupine poisoning of cattle on the ranges. Cattle, however, are more susceptible on a weight basis to poisoning by this plant than are sheep. This suggests that more sheep than cattle are poisoned by lupine because of differences in management procedures.

Some of the Astragalus species that are classified as locoweeds may cause malformations and abortions in livestock grazing them. Skeletal malformations induced by consumption of the plant may be any or all of the following: curvature and rigidity of the joints, aplasia of the mandible, hypermobility of the stifle joint, flexture of the carpus, and a greatly increased incidence of contracted tendons (James et al., 1967). Abortions may occur in as many as $60 \%$ of the sheep poisoned by locoweed, and can occur any time during the gestation period (James et al., 1967, 1969; Mathews, 1932).

Ewes fed locoweed between their 90th and 120th days of gestation produce fetuses with enlarged hearts, spleens, and thyroids. Bones of lambs from these ewes appear osteoporotic. Fetal edema may also be present (James, 1972) and many lambs are small and weak at birth, and may not survive. There appears to be a higher than normal death rate in normal appearing lambs that are born to locoed ewes (Balls et al., 1973).

The toxic agent(s) in the locoweed is not known.

\section{Astragalus Plants}

The teratogenic problems associated with the Astragalus plants just discussed are only one of several toxic phenomena ascribed to this group of plants. Over 300 species of Astragalus grow in North America (Kingsbury, 1964). These can be divided into groups according to their effect on animals: (1) those that are acutely toxic (Anonymous, 1968), (2) those chronically toxic (MacDonald, 1952, (3) those that cause the locoweed syndrome (Marsh, 1909), (4) those that are toxic due to their selenium content (Rosenfeld and Beath, 1964), and (5) a group that is nontoxic.

A. miser represents the species that are acutely toxic to animals. Animals grazing this plant die quickly after consuming a lethal dose. The toxic agent is an organic nitro compound, miserotoxin (Stermitz et al., 1969). The signs of poisoning include nervousness, weakness, rapid weak pulse, coma, convulsion, and death (Anonymous, 1968).

Those species causing chronic toxicity characterized by huskiness in the voice and posterior paralysis include $A$. emoryanus (Mathews, 1940) and A. tetrapterus (Marsh and Clawson, 1920). There is an overlap in symptoms between Astragalus plants causing acute intoxication and those causing chronic poisoning. The toxic agent is the same, and the difference in effect appears to be related to rate of consumption.

The locoweeds are so called because of their effect on animals. Approximately 13 species of Astragalus are included in this grouping, which also includes some species of the genus Oxytropis. The consequences of animals grazing the locoweeds include: (1) habituation, (2) emaciation, (3) neurological disturbances, and (4) reproductive disturbances (James et al., 1969).

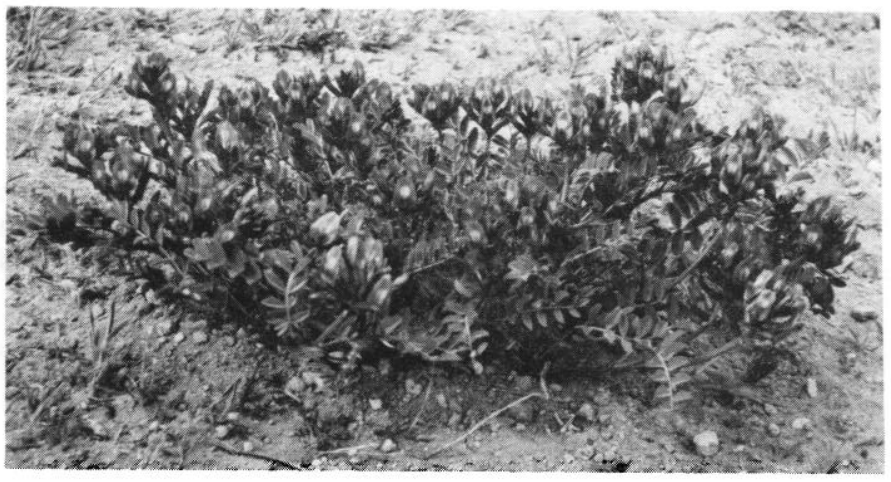

Locoweed (Astragalus lentiginosus) one of the plants most damaging to livestock in the West.

Locoweeds are not especially palatable to livestock (Marsh, 1909); however, when the loco is green and other forage dry, livestock may be enticed to eat it (James et al., 1968). When an animal starts to graze the plant, it develops a liking for it and may graze it to the exclusion of other forage (Marsh, 1909). Signs of poisoning do not develop until animals have grazed this plant for about 30 days. They include depression, dullness, excitement when disturbed, and loss of sense of direction (Marsh, 1909). Symptoms may disappear after an animal is prevented from grazing the plant; however, it may show signs of poisoning the remainder of its life when placed under stress (James et al., 1968). If grazing of the locoweed is allowed to continue, the animal becomes recumbent and eventually dies (James et al., 1968).

In addition to the reproductive consequences already discussed, sexual desire and spermatogenesis of the male (James and Van Kampen, 1971) and estrus of the female is suppressed in locoweed poisoning. If the animal is removed from the plant, these functions are recovered. 
Pathologic changes in locoweed-poisoned animals have been described as cytoplasmic vacuolation of the neurons of the central nervous system and the cells of certain internal organs (Van Kampen and James, 1969).

Poisoning can best be diagnosed by observation of the gross symptoms, by identifying the histopathologic lesions, and by determining that the plant has been grazed.

Approximately 21 species of Astragalus, including $A$. bisulcatus (Rosenfeld and Beath, 1964) and A. pattersonii, accumulate the toxic element selenium from the soil (Rosenfeld and Beath, 1964). Plants other than Astragalus can accumulate selenium. These include Stanleya pinnata, Atriplex nuttallii, and certain grasses (Rosenfeld and Beath, 1964).

Intoxication of livestock by seleniferous plants has been classified as both acute and chronic (Moxon, 1937; Rosenfeld and Beath, 1964). In acute poisoning the animal dies rapidly after eating the seleniferous plant.

Chronic selenosis has been classified into two types: blind staggers and alkali disease. Blind staggers is characterized by the animal wandering, moving in a circle, having little desire to eat or drink, and frequently having impared vision. Alkali disease is characterized by lack of vitality, anemia, stiffness of joints, lameness, roughened hair coat, and hoof deformities (Rosenfeld and Beath, 1964). The selenium content of the hair can be used as a diagnostic aid. Jensen et al. (1956) have suggested that blind staggers is not due to selenium intoxication but to some other etiologic agent.

Plants such as A. bisulcatus, A. pattersonii, and Stanleya pinnata have been termed as obligate species because they require selenium for growth and are therefore termed indicator or converter plants. Other plants may accumulate selenium if they grow on soil high in selenium. In these areas, the grasses or other shallow-rooted plants that accumulate selenium may be dependent on the deeper rooting plants to bring selenium to the soil surface before they can accumulate it.

\section{Larkspur}

The larkspurs (Delphinium spp.) cause more cattle deaths than any other plant species grazed on the ranges of the western United States and Canada (Kingsbury, 1964). They are less

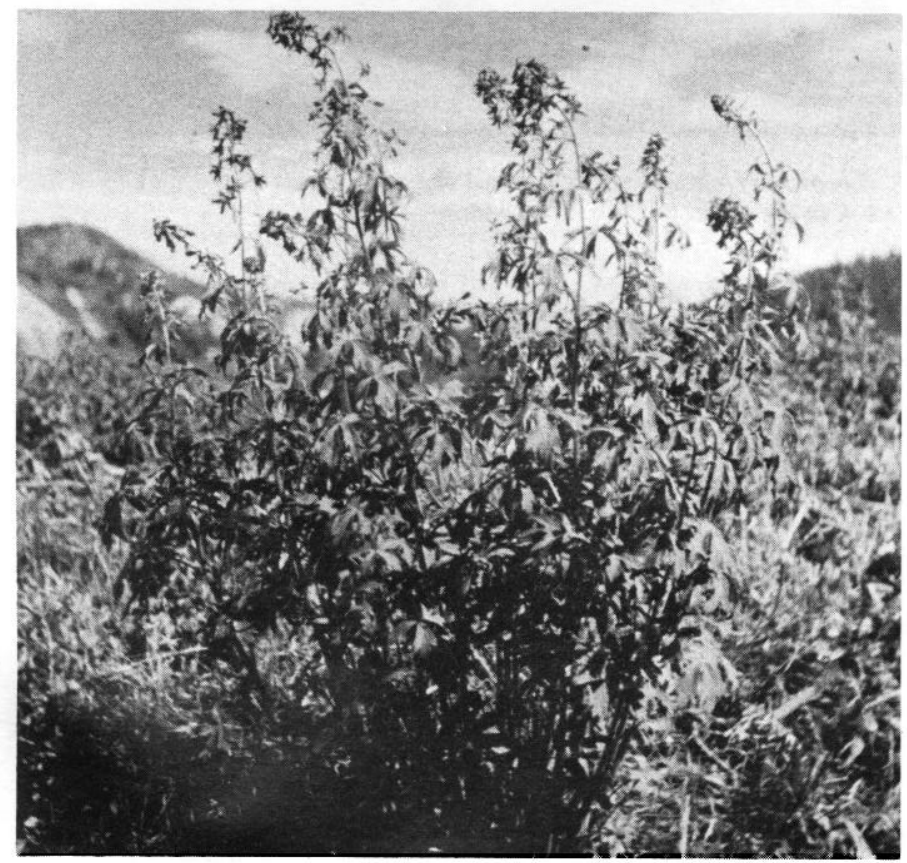

Larkspur (Delphinium barbeyi) a plant growing in high mountain areas which causes many cattle deaths. toxic to sheep. Larkspur are of two types, low and tall. Low larkspurs are smaller plants that inhabit the drier plains and foothill areas, while the tall larkspurs are larger, more robust plants growing in the higher mountains or sites with abundant soil moisture. Low larkspurs include species as D. nelsonii and $D$. andersonii, while the most important representatives of the tall larkspurs are $D$. barbeyi, D. occidentale, and D. glaucum.

Both groups of larkspur are toxic and animal responses to poisoning are similar. However, there are variations in toxicity associated with the species eaten and stage of plant growth. Low larkspurs grow early in the season and poisonings occur in the spring prior to hot weather. Tall larkspurs found at higher elevations grow later in the year, and poisonings occur primarily in the summer and fall.

Young plants of both groups of larkspur are most toxic. Toxicity decreases as the plants mature, but it again increases in the seed stage.

I he larkspurs are readily grazed by cattle, which makes prevention of poisoning more difficult than with most poisonous plants. However, as with many other poisonous plants, cattle may graze and utilize small amounts of the plant over prolonged periods without apparent effect. Rapid consumption of larger amounts in short periods of time may result in death in a very short time. Compounds responsible for larkspur toxicity are alkaloids which appear to affect the nervous system principally. Thus, signs are related to a general weakness of the animal. It may display a straddle-legged stance as it attempts to stand and may suddenly collapse if pushed or pressed (Anonymous, 1968). After collapse it may or may not regain sufficient strength to arise. Thus, the quieter a poisoned animal can be kept the better chance it has for survival. At present prevention lies either with avoiding grazing or control of the plants with herbicides. Tall larkspur can be successfully controlled by spraying it two successive years with 2,4,5-T (Cronin, 1974).

\section{Hemlock}

Two common poisonous plants which are often confused due to their names and similar appearance (Kingsbury, 1964) are water hemlock and poison hemlock. Water hemlock, Cicuta species, is found only in swampy or wet habitats as along streams, in marshes, or other areas which are wet at least part of

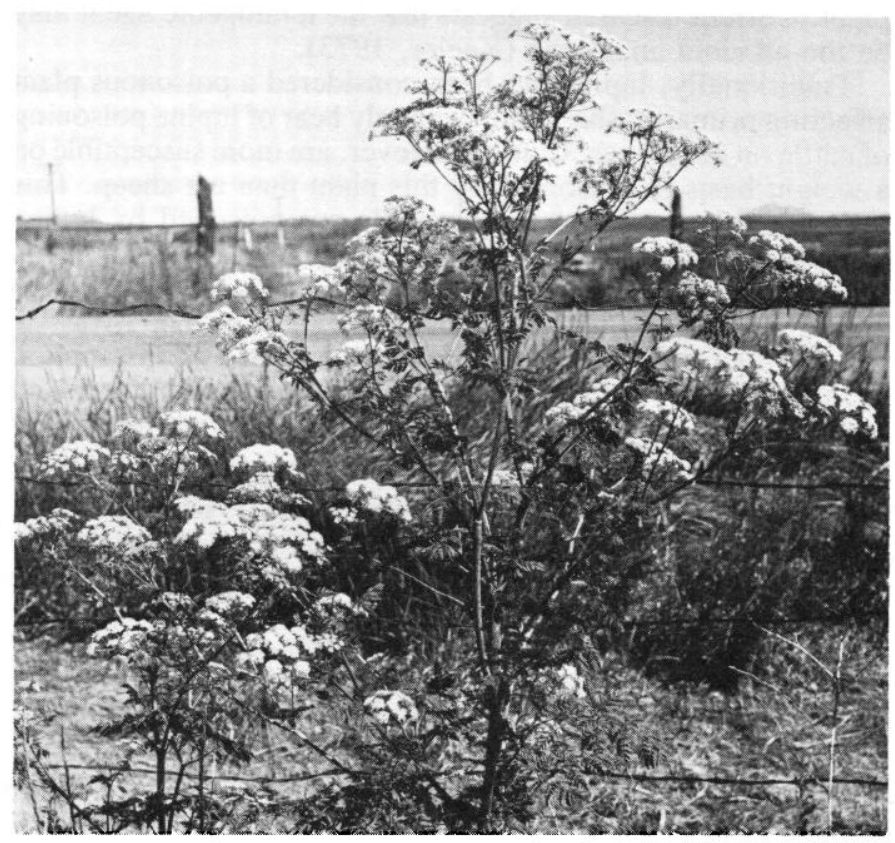

Poison hemlock (Conium maculatum) is toxic to livestock and may cause birth defects in calves. 
the year. It is of the Umbelliferae family and has as its distinguishing features fascicled tuberous roots, chambered swollen rootstock, and a characteristic odor (Anonymous, 1968). It is toxic to all classes of livestock and humans, and poisoning in humans is not uncommon.

Cicutoxin, the toxic principle of water hemlock, is one of the most powerful of the plant toxins. Cicutoxin acts directly on the nervous system, causing violent convulsions. Death follows rapidly after consumption of a lethal dose. Control of the plant or avoiding it is about the only means of the prevention of poisoning.

Poison hemlock can be distinguished from the water hemlock by observing that the stems are usually spotted with purple on the lower portions and that the root is usually an unbranched white tap root. Poison hemlock has a mousy odor (Anonymous, 1968).

The toxic principle is coniine, a volatile alkaloid which is also toxic to all classes of livestock and humans. The signs of poisoning include nervousness, trembling, ataxia, dilation of the pupils, weakened and slowed heartbeat, coldness of extremities, coma, and death from respiratory failure.

This plant has recently been shown to be responsible for a birth defect in calves similar to the "crooked calf disease" caused by lupine (Keeler, 1974). Prevention of poisoning lies in control of the plant and avoidance of it. Animals eat this plant only when forced to do so.

\section{Plants Containing Pyrrolizidine Alkaloids}

Some of the most insidious problems in livestock are caused by plants which contain pyrrolizidine alkaloids (PAs) (Bull et al., 1968). There are many PAs, all of which are structurally similar and found in several plant genera throughout the world. Senecio, Crotalaria, and Heliotropium are representative genera, with three Senecio species being of most importance in this country: tansy ragwort (Senecio jacobaea), found in coastal Washington, Oregon, and California; threadleaf groundsel (Senecio longilobus); ${ }^{*}$ and Riddell's groundsel (Senecio riddellii), found in semidesert areas of the Southwest.

Polsoning caused by PA-containing plants is usually chronic unless abnormally large quantities of plants are consumed in a short time. The primary target in the animal is the liver, and most animals are susceptible to PAs. Sheep are generally more resistant than horses and cattle.

PAs produce a cirrhosis-like condition of the liver, which may not manifest itself until weeks or months after a toxic dose has been consumed (Bull et al., 1968). Signs of poisoning may appear gradually and include: depression, anorexia, weakness, uneasiness, emaciation, and reduced sensibility; or the affected animal may suddenly fill with fluid in the abdominal area, become either diarrheic or constipated, may become very dull rapidly, and may walk or pace aimlessly and die suddenly in a 2to 4-day period. Due to the delay in appearance of symptoms, it is difficult to diagnose and many poisonings go unrecognized or are blamed on other causes. The most consistent postmortem findings are a tough, fibrotic liver with an enlarged gall bladder. Definitive diagnosis may be made through histopathologic examination of the liver.

Since symptoms often do not appear until an animal has received a lethal dose of the plant, treatment in PA poisoning is usually of little value.

The groundsels flourish principally in time of overgrazing and drought, and plants are eaten primarily when ranges are dry and other food is scarce (Sperry et al., n.d.). As in tansy ragwort poisonings, many toxicities may go unrecognized and the relationship of groundsel poisoning to other stresses may be of more importance than is realized.

Tansy ragwort was introduced into the northwest United States probably through a seaport early in this century. Though it was recognized as a plant poisonous to livestock and was nown to be in the area, little concern has been shown until the past 10 years (Johnson, 1976). It has now gained such a strong foothold that eradication is virtually impossible and numerous losses occur annually in horses and cattle grazing the young plant and eating contaminated ensilage and hay. Additionally, there are public health concerns as PAs are known to be hazardous to humans.

\section{Some Related Members of the Compositae Family}

A few plants in the compositae family are especially troublesome to the livestock industry. These include sneezeweed (Helenium hoopesii), bitterweed (Hymenoxys odorata), rubberweed (Hymenoxys richardsonii, var. floribunda) and broomweed (Gutierrezia microcephala). Their effects on livestock are similar. All four plants green early in the spring and remain green into late fall. Livestock generally eat these plants (with the exception of sneezeweed) only when hungry or searching for green feed in early spring. Increased populations of these plants have been considered indicative of overgrazing. All are more troublesome to sheep than to cattle except broomweed. All have caused considerable losses to the livestock industry. All except broomweed have recently been shown to have the same toxic principle, a sesquiterpene lactone (Ivie et al., 1975).

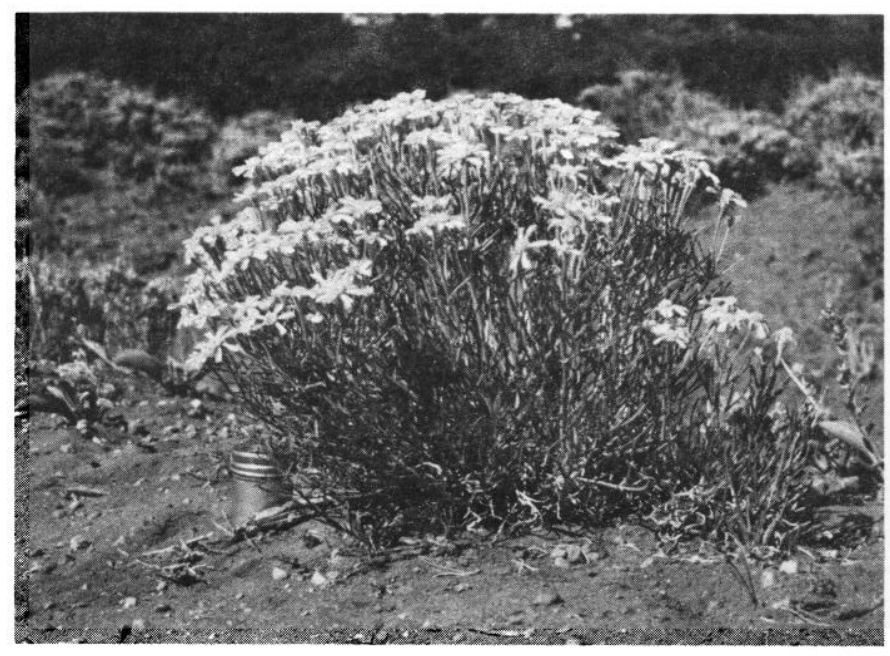

Colorado rubberweed (Hymenoxys richardsonii) which causes serious livestock losses.

Sneezeweed is a herbaceous perennial growing in the Intermountain West at elevations above 7,000 feet. Sneezeweed poisoning (spewing sickness) occurs primarily when overgrazing encourages the plants to increase in number. Both cattle and sheep are poisoned by this plant, but it is principally a problem in sheep. Poisoning occurs only when sheep graze the plant continually over extended periods (about 2 weeks). Signs of poisoning include dullness, depression, weakness, and in more advanced intoxication, vomiting, which is a sign of permanent injury. Lesions include gastrointestinal irritation and congestion of the liver and kidneys (Anonymous, 1968). Prevention lies in alternating (at 10-day intervals) between grazing sneezeweed-free and infested ranges.

Rubberweed, or pingue, is a perennial herbaceous plant that grows in dry soils at elevations of 4,000 to 10,000 feet in the southern parts of Utah and Colorado, and the northern part of Arizona and New Mexico. It is principally a problem in range sheep. Signs of poisoning include salivation, anorexia, rumen stasis, abdominal pain, uneasiness, weakness, and prostration. Lesions are those associated with gastrointestinal irritation and degeneration of the liver.

Bitterweed, an annual, grows primarily in southwestern United States. Signs of bitterweed intoxication include anor- 
exia, salivation, vomiting, depression, and weakness (Sperry et al., n.d.). Lesions are confined primarily to the lungs and gastrointestinal tract. Prevention of intoxication at the present time lies in avoiding areas where these plants can be grazed in excessive amounts.

Broomweed is a perennial that grows on the drier ranges of the West (Sperry et al., n.d.). In some areas it covers many thousands of acres of rangeland but toxicity to livestock is related to the soil types on which it grows; it is reported to be most toxic on sandy soil. Cattle and sheep are poisoned if forced to graze heavily on broomweed. Signs of broomweed poisoning in cattle and sheep are listlessness, anorexia, rough hair coat, diarrhea or constipation, mucus in the feces, and vaginal swelling in females. The principal result of such poisoning is. abortion and the production of light-weight and weak offspring, and retention of the placenta, which may also occur in dams giving birth to normal young. Lesions in the dam include severe digestive tract irritation, and degenerative changes of the liver and kidneys.

\section{Cyanide-Producing Plants}

There are a number of plants that under the proper conditions produce an excess of the glycoside of the hydrocyanic acid. The two important range plants that accumulate hydrocyanic acid are chokecherry (Prunus virginiana) and arrowgrass (Triglochin maritima). The hydrocyanic acid is produced in excessive amounts during drought, frost, or other conditions that might stress the plants (Kingsbury, 1964).

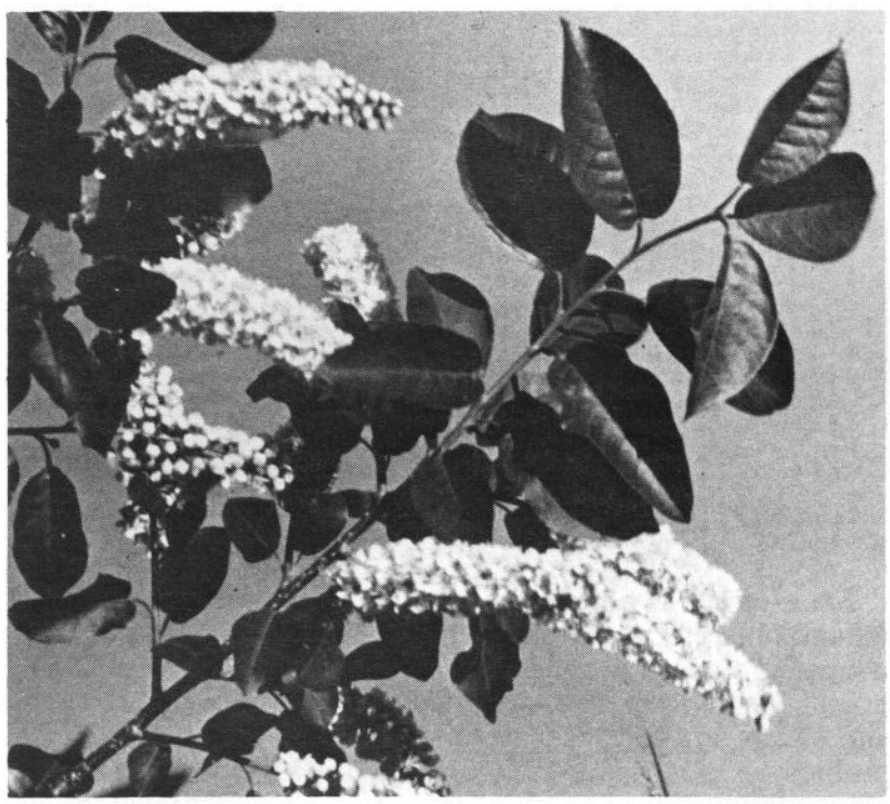

Chokecherry (Prunus virginiana) produces hydrocyanic acid which is very toxic to livestock

Four factors are of importance in cyanide poisoning: (1) cyanide content of the plant, (2) rate of intake, (3) speed of release of cyanide from the plant material, and (4) relative rate of absorption and detoxification by the animal's tissue (Kingsbury, 1964). The cyanide content of the plant as indicated varies with environmental conditions. If the toxic plant material is eaten slowly, enzymatic processes in the body can detoxify the cyanide. The release of the toxic plant material requires a certain amount of moisture. Thus, drinking water may prompt a quick release of cyanide material and rapid death of the animal may result.

Signs of intoxication include nervousness, abnormal respiration, trembling, blue coloration of the lining of mouth, spasm or convulsion ending in death (Anonymous, 1968).
Awareness of the cyanide-producing plants and avoiding them during periods of potential danger is the best means of prevention.

\section{Oxalate-Producing Plants}

Oxalate-producing plants are worldwide in distribution. A fairly complete list of plants that may contain dangerous amounts of soluble oxalates may be found in Kingsbury (1964).

Oxalates are found in plants in both soluble and insoluble forms. Soluble oxalates are toxic to livestock; insoluble oxalates are not. The soluble oxalates have a strong affinity for calcium. Calcium oxalate is the principal insoluble form. The two most important toxic oxalates are sodium oxalate found in sap that is mildly acidic (pH6), and acid potassium oxalate found in sap that is highly acidic (pH2) (James, 1968).

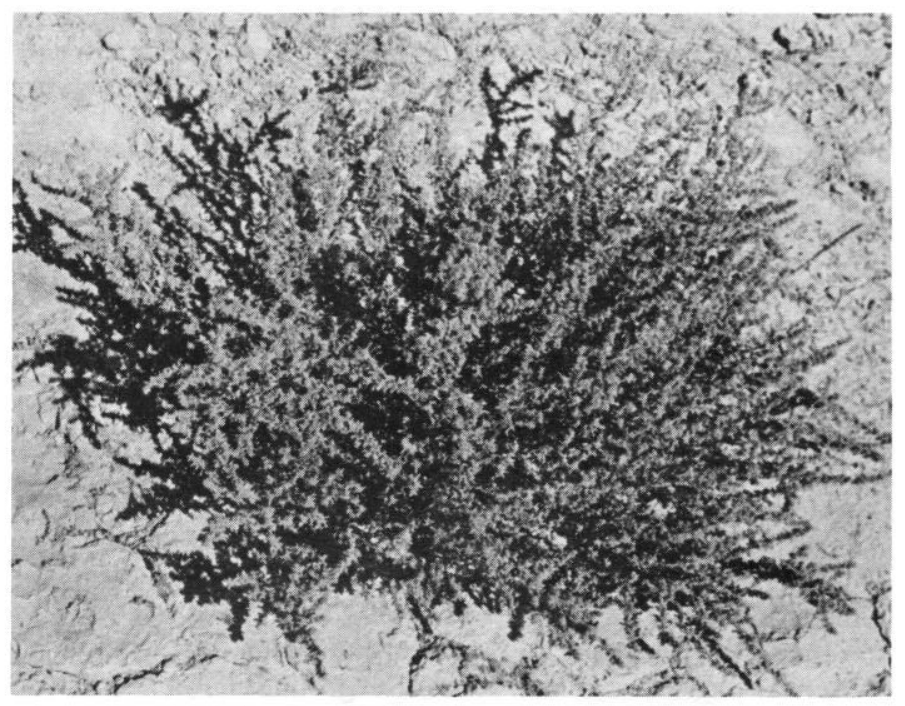

Halogeton (Halogeton glomeratus) an oxalate-producing plant growing in the Great Basin area.

There are two principal oxalate-producing plants in North America. They are halogeton (Halogeton glomeratus), a naturalized annual introduced from Asia, and greasewood (Sarcobatus vermiculatus), a native perennial. Both plants belong to the Chenopodiaceae family and are readily grazed by sheep and cattle. They have caused a multitude of sheep deaths but only occasional deaths in cattle.

Halogeton usually contains $15 \%$ to $18 \%$ of its dry weight as oxalate but may reach as high as $36 \%$; greasewood contains slightly less. Oxalate content varies with factors such as moisture, site of growth, stage of growth, and leaching (Williams, 1960).

When oxalate is consumed by a ruminant it combines with calcium to form insoluble oxalate and is excreted; or it may be degraded by the rumen microorganisms; or it is absorbed from the rumen where it may exert its toxic effects.

Oxalate produces its toxic reactions in three principal ways. (1) It may be absorbed into the blood stream from the rumen, where it may combine with calcium resulting in a hypocalcemia (James, 1968). (2) Accumulation of calcium oxalate crystals may mechanically damage renal tubules and rumen mucosa and thus interfere with kidney and rumen function (Van Kampen and James, 1969). (3) Oxalate may interrupt energy metabolism by interfering with the enzymes succinic and lactic dehydrogenases (James, 1968). The immediate cause of death may be the disruption of energy metabolism (James, 1968).

Halogeton poisoning in sheep is characterized by depression, weakness, and some salivation. There is increased heart rate, complete stasis of the digestive tract, and finally coma and death 


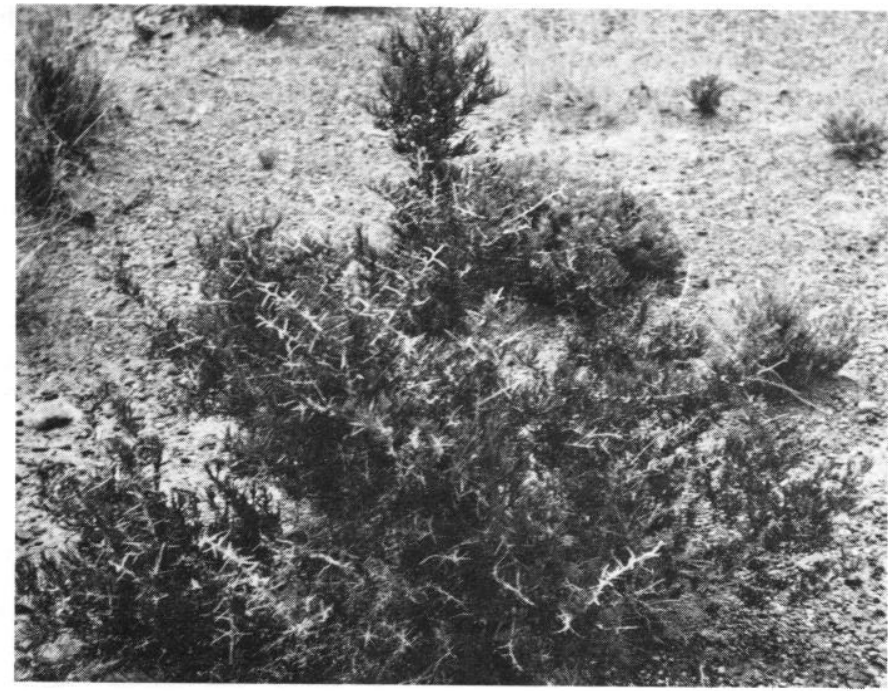

Greasewood (Sarcobatus vermiculatus) an oxalate-producing plant growing on arid areas of the Great Basin.

(Cook and Stoddart, 1953), which usually occurs within about 12 hours. Some animals may linger for several days.

Oxalate poisoning appears to be an all or none situation: i.e., a sheep either eats enough to kill it, or there are few symptomatic effects (James and Butcher, 1972). Sheep can eat large amounts of halogeton with no ill effects if they consume the plants slowly, but are poisoned when they eat large amounts in a short period of time. This usually occurs when they are excessively hungry. Thus, the problem is principally one of management. There is no effective treatment for sheep or cattle poisoned by halogeton.

Prevention of oxalate poisoning can best be attained by following three rules:(1) Move sheep slowly into areas where oxalate-producing plants grow to allow rumen microflora time to become accustomed to degrading oxalate. Oxalate is rapidly degraded by rumen microflora (James et al., 1967) and their degradative effectiveness can be increased if oxalate is supplied over a time at small nontoxic levels. The efficiency of these organisms can be increased by as much as $75 \%$ (James et al., 1970) by exposing livestock to gradually increasing amounts of oxalate-producing plants or first allowing them to graze low oxalate-producing plants such as shadscale. (2) Prevent hungry sheep from grazing heavy stands of halogeton. Hunger can result from either insufficient feed or water (James et al., 1970). However, if water is withheld, feed intake declines. (3) Develop grazing plans that allow critical halogeton areas to be approached only after proper preparations have been made for the sheep to graze these areas (James and Butcher, 1972).

Various calcium-containing mineral supplements have been recommended for the prevention of halogeton poisoning (James and Binns, 1961). However, they are ineffective because the high level of calcium necessary to prevent poisoning can be maintained for only a short time after the calcium is consumed (James and Johnson, 1970).

\section{Nitrates - Nitrites}

Several plants have the potential for containing nitrate at toxic levels. These include crop plants such as oat hay, corn, and soybeans, and weeds such as pigweed (Amaranthus retroflexus and A. palmerii), and lambsquarter (Chenopodium album) (Kingsbury, 1964). Plants containing more than $1.5 \%$ nitrate $\left(\mathrm{KNO}_{3}\right.$ dry weight) may prove lethal to livestock. Nitrate poisoning also results from animals eating fertilizers and drinking water high in nitrate.
Factors that influence the nitrate content of plants include drought and fertilization. Treatment with the herbicide 2,4-D may increase nitrate accumulation by the plant as well as cause some unpalatable plants to become palatable.

In the rumen of an animal the nitrate is converted to nitrite. The nitrite is about 10 times more toxic than is nitrate

The gross symptoms of acute nitrate poisoning include cyanosis, severe dyspnea, trembling, and weakness. Nitrate poisoning can be successfully treated.

Chronic poisoning can occur when animals eat feeds containing between $0.5 \%$ and $1.5 \%$ nitrate. The response is varied but the principal result is unthriftiness.

\section{Photosensitization}

Photosensitization is an allergy-like disease caused by a hypersensitivity of animals to sunlight (Johnson, 1974). It occurs in livestock more frequently than realized. Photosensitivity results when a phototoxic substance is allowed to reach the skin from an internal route, i.e., it is eaten by the animal, is absorbed from the digestive tract into the bloodstream, and thus circulated to the skin (Johnson, 1974). Here it is acted on by sunlight to cause its irritating effect. This type is called primary photosensitization and may be caused by many chemical compounds, usually pigments which may contaminate water or feed consumed by livestock. Plants which contain primary photosensitizers include buckwheat (Polygonum fagopyrum), St. Johnswort (Hypericum perforatum), and desert parsley (Cymopterus watsonii) (Kingsbury, 1964).

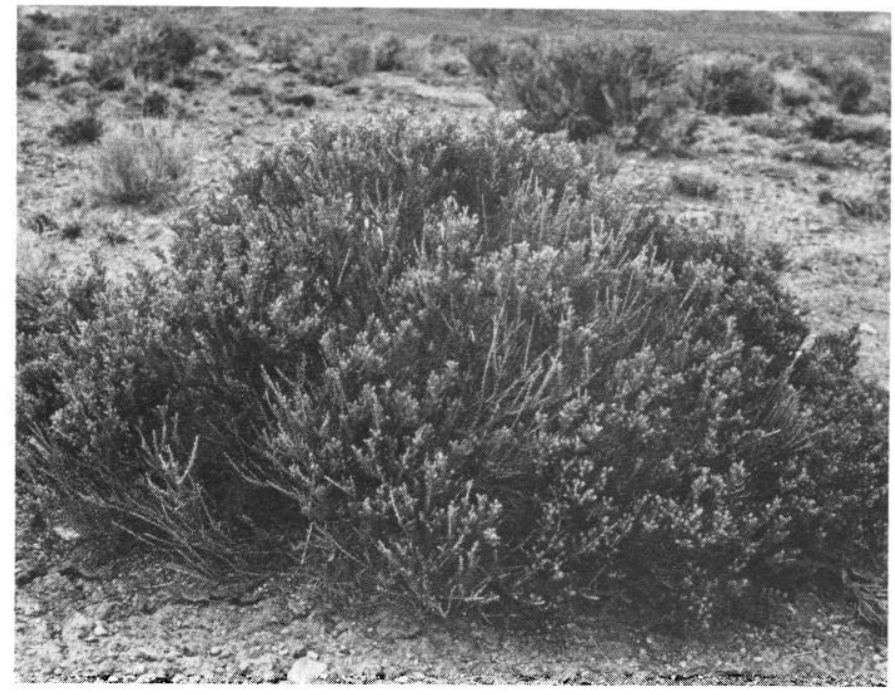

Horsebrush (Tetradymia glabrata) a plant implicated in photosensitization in sheep.

Of far more importance to livestock, however, are those classes as secondary photosensitizers. In this type the phototoxic agent is a pigment called phylloerythrin, a product of chlorophyll breakdown. Normally chlorophyll is broken down in the stomach and the resultant phylloerythrin absorbed into the blood which goes to the liver. The normal functioning liver removes the phylloerythrin and it is excreted in the bile. A liver damaged in such a way that it cannot remove phylloerythrin allows this pigment to reach the skin and thus be activated by sunlight.

Photosensitization occurs only in skin that is unprotected by thick wool or hair, or by skin coloration. Thus, in sheep the problem occurs principally in the face, ears, udder, or unprotected rear parts. In cattle it occurs in the white or light-colored skin areas. Symptoms of photosensitization are: uneasiness, itching and thus rubbing of sensitive areas, redness of the skin, 
fluid accumulation in the affected areas which may be so severe that the skin cracks and fluid leaks out. Affected skin may die and slough off in large sheets, especially in cattle. Sheep may also lose their herding instinct as they seek shade.

Though there are several plants in the western United States which have been incriminated in secondary photosensitization, only the horsebrushes (Tetradymia glabrata and $T$. canescens) are responsible for sizeable losses to livestock. Photosensitization caused by these plants in sheep is known as "bighead" because tissue swelling may cause the head to be almost twice its normal size. Though the extremely large losses of years ago no longer occur, many sheep are still affected when they are trailed through horsebrush infested areas. Livestockmen using these areas must be well informed and continually alert, and may be forced into expensive and time-consuming practices to avoid the problem at times of greatest risk.

Though one of the tetadymia liver toxins has recently been isolated, its relationship to photosensitization has not been determined (Jennings, 1974). Apparently the liver changes necessary for secondary photosensitization to occur are subtle, and preconditioning of the sheep by other range plants, notably black sagebrush, is necessary for tetradymia-related photosensitizations to occur (Johnson, 1974).

Sheep usually eat sufficient $T$. glabrata to damage them only when forced by poor management practices, or under unusual weather conditions when they may change their feeding habits.

There is no treatment available to relieve severe symptoms after they develop; however, less severe symptoms may be relieved by moving animals to sheltered areas where good food is available.

As with many other poisonous plant problems, knowledge of the condition (and its relation to other range plants) may allow the institution of proper management practices to avoid the intoxication.

\section{Pine Needle Abortion}

Ponderosa pine (Pinus ponderosa) causes abortions in cattle when grazed during pregnancy (Stevenson, 1972). Pine needleinduced abortions in cattle have been reported in western Canada, Washington, Oregon, Idaho, Montana, Wyoming, South Dakota, California, Colorado, and New Mexico, and probably occur to some extent in all states where ponderosa pine grows. Abortions occur primarily during the late fall, winter, and early spring. Several factors seem to induce cattle to eat pine needles: (1) sudden weather changes, (2) hunger, (3) changes in feed, (4) sudden access to pine needles, and (5) boredom. Field observations indicate that both dried and green needles can cause abortions.

Abortions may start as early as 24 hours after pine needles are consumed and continue for 2 weeks after the cattle are removed from access to the needles. If the abortion is near term, the calf may survive. The abortions are characterized by weak parturition contractions, excessive uterine hemorrhages, and incomplete dilation of the cervix. A persistently retained placenta is a constant finding regardless of stage of gestation.

\section{Rules of Thumb for Preventing Livestock Poisoning by Plants}

1. Know your poisonous plants-especially those associated with your range.

2. Know how these plants affect your livestock and the conditions under which they are poisonous.

3. Avoid holding animals on, trailing through, or unloading from trucks into areas infested with poisonous plants. If these situations cannot be avoided, special preparation should be made such as supplemental feeding.
4. Avoid grazing hungry animals in areas infested with poisonous plants. Animals can be made hungry by withholding feed or water and overgrazing. Provide animals with adequate forage, of good variety and quality, and water.

5. Provide an adequate mineral and salt supplement.

6. Where possible, control or eradicate poisonous plants, especially from problem areas.

7. Where possible, develop a grazing plan.

8. Keep your range in good condition. Avoid overgrazing.

9. It is the consensus of most people who have written on poisonous plants that good management will prevent most cases of plant poisoning.

\section{Literature Cited}

Anonymous. 1968. Twenty-two plants poisonous to livestock in the Western United States. U.S. Dep. Agr. Bull. 327.

Balls, Lew Dell, and L. F. James. 1973. Effect of locoweed (Astragalus spp.) on reproductive performance of ewes. J. Amer. Vet. Med. Ass. 162:291-292.

Binns, Wayne, Lynn F. James, James L. Shupe, and George Everett. 1963. A congenital cylopian-type malformation in lambs induced by maternal ingestion of a range plant, Veratrum californicum. Amer. J. Vet. Res. 24:1164-1175.

Binns, Wayne, Rickard F. Keeler, and Lew Dell Balls. 1972. Congenital deformities in lambs, calves, and goats resulting from maternal ingestion of Veratrum californicum: hare lip, cleft palate, ataxia and hypoplasia of metacarpal and metatarsal bones. Clin. Tox. 5:245-261.

Ball, L. B., C. C. J. Culvenor, and A. T. Dick. 1968. The pyrrolizidine alkaloids, their chemistry, pathogenicity, and other biological properties. 1st ed. John Wiley and Sons, Inc., New York.

Cook, Wayne, and L. A. Stoddart. 1953. Halogeton poisoning in Utah. Utah Agr. Exp. Sta. Bull. 364.

Cronin, E. H. 1974. Evaluation of some herbicide treatments for controlling tall larkspur. J. Range Manage. 27:219-222.

Ivie, G. Wayne, Donald A. Witzel, Wener Herz, Ramamurthi Kannan, James O. Norman, Darcy D. Rushing, James H. Johnson, Loyd D. Rowe, and Joseph A. Veech. Hymenovin: Major toxic constituent of Western Bitterweed (Hymenoxys odorata DC.) (Accepted for publication J. of Agr. and Food Chem.)

James, Lynn F. 1968. Serum electrolyte, acid-base balance, and enzyme change in acute Halogeton glomeratus poisoning in sheep. Can. J. Comp. Med. 32:539-543

James, Lynn F. 1972. Effect of locoweed on fetal development: Preliminary study in sheep. Amer. J. Vet. Res. 33: 835-840.

James, Lynn F. 1972. Oxalate toxicosis. Clin. Tox. 5:221-243.

James, Lynn F., K. L. Bennett, K. G. Parker, Richard F. Keeler, Wayne Binns, and Ben Lindsay. 1968. Loco plant poisoning in sheep. J. Range Manage. 21:360-365

James, Lynn F., and Wayne Binns. 1961. The use of mineral supplements to prevent halogeton poisoning in sheep. Proceedings Western Section Amer. Soc. Anim. Sci. 12:LXVI. Moscow, Ida.

James, Lynn F., and John E. Butcher. 1972. Halogeton poisoning of sheep. Effects of high level intake. J. Anim. Sci. 35:1233-1238.

James, Lynn F., John E. Butcher, and Kent R. Van Kampen. 1970. Relationship between Halogeton glomeratus consumption and water intake by sheep. J. Range Manage. 23:123-127.

James, Lynn F., and A. Earl Juinson. 1970. Prevention of fatal Halogeton glomeratus poisoning in sheep. J. Amer. Vet. Med. Ass. 154:437-442.

James, Lynn F., and Richard F. Keeler. 1968. Teratogenic effects of aminopterin in sheep. Teratology 1:407-412.

James, Lynn F., Richard F. Keeler, Wayne Binns, and Kent R. Van Kampen. 1969. Locoweed disease. Clin. Tox. 2:13-20.

James, Lynn F., James L. Shupe, Wayne Binns, and Richard F. Keeler. 1967. Abortive and teratogenic effects of locoweed on sheep and cattle. Amer. J. Vet. Res. 28:1379-1388.

James, Lynn F., Joseph C. Street, and John E. Butcher. 1967. In vitro degradation of oxalate and of cellulose by rumen ingesta from sheep fed Halogeton glomeratus. J. Anim. Sci. 26:1438-1444.

James, Lynn F., and Kent R. Van Kampen. 1971. Effects of locoweed intoxication on the genital tract of the ram. Amer. J. Vet. Res. 32:1253-1256.

James, Lynn F., Kent R. Van Kampen, and Gordon R. Staker. 1969. Locoweed (Astragalus lentiginosus) poisoning in horses and cattle. J. Amer. Vet. Med. Ass. 155:525-530.

Jennings, Paul W., Samuel K. Reeder, Jerome C. Hurley, Charles N. 
Caughlan, and G. David Smith. 1974. Isolation and structure determination of one of the toxic constituents from Tetradymia glabrata. J. Org. Chem. 39:3392-3398.

Jensen, R., L. A. Grier, and O. R. Adams. 1956. Polioencephalomalacia of cattle and sheep. J. Amer. Vet. Med. Ass. 29:311-321.

Johnson, A. Earl. 1974. Predisposing influence of range plants on tetradymiarelated photosensitization in sheep. Work of Drs. A. B. Clawson and W. T. Huffman. Amer. J. Vet. Res. 35:1583-1585.

Johnson, A. Earl. 1974. Experimental photosensitization and toxicity in sheep produced by Tetradymia glabrata. Can. J. Comp. Med. 38:406-410.

Johnson, A. Earl. 1976. Changes in calves and rats consuming milk from cows fed chronic lethal doses of Senecio jacobaea (tansy ragwort). Amer. J. Vet. Res. 37:107-110.

Keeler, Richard F. 1972. Known and suspected teratogenic hazards in range plants. Clin. Tox. 5:529-562.

Keeler, Richard F. 1973. Lupin alkaloids from teratogenic and non-teratogenic lupins. Il. Identification of the major alkaloids by tandem gas chromatography-mass spectrometry in plants producing crooked calf disease. Teratology 7:31-36.

Keeler, R. F. 1974. Coniine, a teratogenic principle from Conium maculatum producing congenital malformation in calves. Clin. Tox. 7(2):195-206.

Kingsbury, John M. 1964. Poisonous plants of the United States and Canada. Prentice Hall, Inc., Englewood, Calif.

MacDonald, M. A. 1952. Timber milk vetch poisoning on British Columbia ranges. J. Range Manage. 5:16-21.

Marsh, C. D. 1909. The locoweed disease of the plains. U.S. Dep. Agr. Tech. Bull. 112

Marsh, C. D., and A. E. Clawson. 1920. Astragalus tetrapterus, a new poisonous plant of Utah and Nevada. U.S. Dep. Agr. Circ. 81.

Mathews, Frank P. 1932. Locoism in domestic animals. Texas Agr. Exp. Sta. Bull. 456.
Mathews, Frank P. 1940. The toxicity of red-stemmed peavine (Astragalus emoryanus) for cattle, sheep, and goats. J. Amer. Vet. Med. Ass. 47: 125-134.

Moxon, Alvin L. 1937. Alkali disease or selenium poisoning. South Dakota Agr. Exp. Sta. Bull. 311.

National Academy of Science. 1968. Prenatal and postnatal mortality in cattle. Nat. Acad. Sci. Pub. No. 1685. Washington, D.C. p. 58.

Palludon, B. 1961. The teratogenic effect of vitamin A deficiency in pigs. Acta Vet. Scand. 2:32

Rosenfeld, Irene, and O. A. Beath. 1964. Selenium-geobotany, biochemistry, toxicity and nutrition. Academic Press, New York.

Sampson, Arthur W. 1952. Range management principles and practices. John Wiley and Sons, New York. p. 458.

Schmitz, Ervin M., Barry N. Freeman, and Raymond E. Reed. 1968. Livestock poisoning plants of Arizona. Univ. of Arizona Press, Tucson. p. 6.

Shupe, James L., Wayne Binns, and Lynn F. James. 1967. Lupine, a cause of crooked calf disease. J. Amer. Vet. Med. Ass. 151:198-203.

Sperry, O. E., J. W. Dollahite, G. O. Hoffman, and B. J. Camp. Not dated. Texas plants poisonous to livestock. Texas Agr. Ext. Bull. B-1028. p. 3-4.

Stermitz, F. R., F. A. Norris, and M. C. Williams. 1969. Miserotoxin, a new naturally occurring nitro compound. J. Amer. Chem. Soc. 91:4599.

Stevenson, A. H., Lynn F. James, and Jay W. Call. 1972. Pine needle (Pinus ponderosa) induced abortion in range cattle. Cornell Vet. 52:519-524.

Van Kampen, Kent R., and Lynn F. James. 1969. Acute halogeton poisoning in sheep: Pathogenesis of lesions. Amer. J. Vet. Res. 30: 1779-1783.

Van Kampen, Kent R., and Lynn F. James. 1969. Pathology of locoweed poisoning in sheep. Path. Vet. 6:413-423.

Williams, M. C. 1960. Effects of sodium and potassium salts on growth and oxalate content of halogeton. Plant Physiol. 35:500. 